\title{
Evaluation of complications of administration for tolvaptan after fluid resuscitation in critical care
}

\author{
H Arimoto*, H Rinka, T Miyaichi, A Fuke, J Ishikawa, T Morooka, K Shigemitsu, T Morimoto \\ From ESICM LIVES 2015 \\ Berlin, Germany. 3-7 October 2015
}

\section{Background}

Hypovolemic status (e.g. sepsis, trauma) is common situation in emergency department. The patients should be given a lot of fluid to prevent circulatory collapse with following early goal directed therapy or massive transfusion protocol in ED. ICU physician usually give some diuretics, as the patients are in hypervolemic status. Tolvaptan is an oral, non-peptide, selective antagonist of vasopressin V2-receptor whose action on the distal nephron causes loss of electrolyte-free water. We evaluate the side effects of tolvaptan for overhydrate status after fluid resuscitation in the critical care field.

\section{Methods}

The indications of administration for tolvaptan are overhydration and normal range of serum sodium and renal functions. $7.5 \mathrm{mg}$ or $15 \mathrm{mg}$ tolvaptan tablets were given once a day for a couple of day in refilling phase after fluid resuscitation. Electrolyte and blood gases were followed al least three times a day in all patients. The enrolled patients were divided into the normal-dose group and low-dose group. Any complications, especially serum sodium level, renal function and neurological outcome were compared.

\section{Results}

A total of 62 patients were enrolled in this study. There was no significant difference in the both groups (the lowdose group; $\mathrm{n}=29$, average $8.6 \mathrm{mg} /$ day, the normal-dose group; $\mathrm{n}=33$, average $12.9 \mathrm{mg} /$ day). Though hypersodium was tend to occur in normal-dose group, any mortal complications were not seen in the both groups.

\section{Conclusions}

Administration for tolvaptan is alternative method to improve over-hydration without serious adverse events.

Osaka City General Hospital, Emergency and Critical Care Medical Center, Osaka, Japan

(c) 2015 Arimoto et al.; This is an Open Access article distributed under the terms of the Creative Commons Attribution License (http:// creativecommons.org/licenses/by/4.0), which permits unrestricted use, distribution, and reproduction in any medium, provided the original work is properly cited.
But strict collections of blood sample are recommended to prevent any complications such as central pontine myelinolysis.

Published: 1 October 2015

doi:10.1186/2197-425X-3-S1-A545

Cite this article as: Arimoto et al:: Evaluation of complications of administration for tolvaptan after fluid resuscitation in critical care. Intensive Care Medicine Experimental 2015 3(Suppl 1):A545.
Submit your manuscript to a SpringerOpen ${ }^{\circ}$ journal and benefit from:

- Convenient online submission

- Rigorous peer review

- Immediate publication on acceptance

- Open access: articles freely available online

- High visibility within the field

- Retaining the copyright to your article

Submit your next manuscript at $\boldsymbol{~ s p r i n g e r o p e n . c o m ~}$ 